\title{
Implementing the Code of Ethics for Police Officers as Corruption Actors
}

\author{
Franciska Mifanyira Sutikno and Indah Dwi Miftachul Jannah \\ Postgraduate Program, Faculty of Law, Universitas Airlangga, Surabaya, Indonesia \\ E-mail: franciska.mifanyira.sutikno-2017@fh.unair.ac.id
}

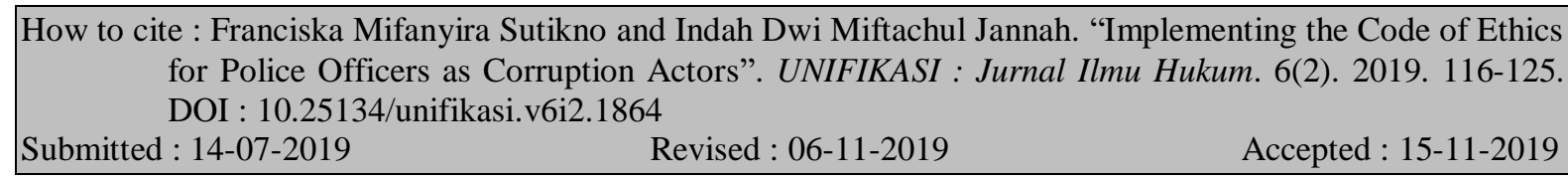

\begin{abstract}
Police is a profession requiring law and code of ethics as a benchmark for any actions and legal consequences. The code of ethics in the State Police of the Republic of Indonesia is applied in corruption along with the applicable law. This study aims to analyze and compare the implementation of the code of ethics of the Police in corruption in Indonesia and Singapore. This study applied a normative juridical approach. The results showed that the code of ethics is internal, administratively binding and implemented in Indonesia and Singapore following the legislations in a coordinated manner. The conclusion of the study is that the implementation of the code of ethics in corruption is carried out without violating the provisions of criminal acts processing by the authorities.
\end{abstract}

Keywords: Indonesia, Police, Code of Ethics, Singapore, Corruption.

\section{Pengimplementasian Kode Etik pada Polisi sebagai Pelaku Tindak Pidana Korupsi}

Abstrak : Polisi merupakan suatu profesi yang membutuhkan hukum dan kode etik sebagai menjadi tolak ukur tindakan dan akibat hukumnya. Kode Etik dalam Polri diterapkan dalam tindak pidana korupsi beriringan dengan hukum yang berlaku. Tujuan dari penelitian adalah untuk menganalisis dan membandingkan pengimplementasian kode etik polri dalam tindak pidana korupsi di Indonesia maupun Singapura. Metode penelitian yang digunakan dengan metode pendekatan yuridis normative yaitu peraturan perundang-undangan dan perbandingan. Hasil penelitian menunjukkan bahwa kode etik bersifat internal, mengikat secara administratif dan pengimplementasian di Indonesia dan Singapura mengikuti ketentuan peraturan perundang-undangan secara koordinatif. Simpulan penelitian adalah pengimplementasian kode etik dalam tindak pidana korupsi dilakukan dengan tidak melanggar ketentuan pemprosesan tindak pidana oleh otoritas.

Kata Kunci: Indonesia, Kepolisian, Kode Etik, Singapura, Tindak Pidana Korupsi.

\section{INTRODUCTION}

In a legal state, society is inseparable from the presence of law and law enforcers. The law enforcers are sheltered in legal institutions that are in line with the legal system applied in the country in accordance with the principle of Check and Balance. ${ }^{1}$ The existence of a state institution, namely the state police of the Republic of Indonesia, is a form of legal protection provided by the state for the society and government systems. The perfect law cannot be well implemented, if law enforcement is not run optimally.

One of criminal acts that still commonly exists in developed and developing countries is corruption which has a huge effect. The government and police as well as the Corruption Eradication Commission have carried out various enforcement efforts, namely the formation and implementation of Dangerous Condition Law and Officials' Retooling Committee as well as the formation of Corruption Eradication Commission Law. Yet, in its practice, these enforcement efforts face various

\footnotetext{
${ }^{1}$ Ahmad Yani, " Sistem Pemerintahan Indonesia : Pendekatan Teori dan Praktik Konstitusi Undang - Undang Dasar 1945", Jurnal Legislasi Indonesia, Volume 15, Nomor 2, Juli 2018, 57.
} 
challenges, especially with the increase number of corruptors spreading within the internal body of law enforcers. ${ }^{2}$

Police officers, who are expected to be able to carry out their functions in a professional and integrated manner, are also exposed to the threat of corruption as proved by a corruption case in the state police on a Driver License Procurement, ${ }^{3}$ involving police officers. ${ }^{4}$ This fact indicates that police officers, who are always bound in the code of ethics and legislations, are also vulnerable to corruption. Based on the description, this study tries to analyze the characteristics of the code of ethics of police in Indonesia and the comparison of law on the imposition of sanction on police officers proven to commit corruption in Singapore and Indonesia?.

\section{RESEARCH METHODS}

This study applied a Positivist Normative method by employing several approaches, namely the statutory approach and the legal comparative approach. Here, the statutory approach was used to analyze the code of ethics in Indonesia. Meanwhile, the comparative approach was used to compare the implementation of law, especially the code of ethics of police in Indonesia and Singapore. Singapore was selected as the object of legal comparison by considering the status of Singapore as a developed country in ASEAN and a country that has a system of law enforcement against corruption.

\section{RESULTS AND DISCUSSION}

\section{The Characteristics of the Profession Ethical Code of the State Police of the Republic of Indonesia}

The code of ethics emerges in legal profession with respect to the presence of morals and ethics. ${ }^{5}$ Those morals and ethics are then not only implemented and intended to bind the profession, but also reflected in professional practices related to society. ${ }^{6}$ The code of ethics can differ in various professions, but it has the same aim which is to distinguish appropriate and correct actions, and vice versa. ${ }^{7}$ The Code of Ethics is also intended to help law enforcers carry out their work effectively and authoritatively. ${ }^{8}$ The code of ethics relating to morals will be binding with the existence of written and coercive recognition in every legal institution. ${ }^{9}$ This ethic has previously been implemented in the Decree of the People's Consultative Assembly No. IV/MPR/2001 which emphasizes integrity, honesty, trustworthiness, responsibility and trust for the state administrators.

Furthermore, the Profession Ethical Code of the State Police of the Republic of Indonesia emphasizes regulations relating to personality, statehood, institutions and public relations. ${ }^{10}$ The Profession Ethical Code of the State Police of the Republic of Indonesia is not only based on professional needs, but has also been regulated in Article 34 and Article 35 of Law No. 2 of 2002 concerning The State Police of The Republic of Indonesia (Polri) which emphasizes the existence of

\footnotetext{
${ }^{2}$ ACCH atau Anti Corruption Clearing House, "Penindakan" 31 Desember 2018, https://acch.kpk.go.id/id/statistik/tindakpidana-korupsi, Accessed 6 Agustus 2019.

3 Andylala Waluyo , VOA Indonesia, "KPK Jerat 2 Jenderal Polisi dalam Kasus Korupsi 198 M", 3 Agustus 2012, https://www.voaindonesia.com/a/kpk-jerat-2-jenderal-polisi-dalam-kasus-korupsi-rp-198m/1454257.html Accessed 14 Juli 2019.

4 M Azhar dan PDAT, Tempo, "Jenderal Polisi di Pusaran Korupsi", 7 Agustus 2012, dapat diakses di https://nasional.tempo.co/read/421944/jenderal-polisi-di-pusaran-korupsi/full\&view=ok, Accessed 14 Juli 2019.

5 Abdul Wahid et.al dalam Sadjijono, Etika Profesi Hukum Suatu Telaah Filosofis terhadap Konsep dan Implementasi Kode Etik Profesi POLRI, Laksbang Mediatama, Yogyakarta, 2009, 9

${ }^{6}$ Frans Magnis Suseno, Etika Abad ke-20, Kanisius, Yogyakarta, 2006, 35

${ }^{7}$ Lundu Harapan Situmorang, "Fungsi Kode Etik Kepolisian dalam Mencegah Penyalahgunaan Wewenang sebagai Aparat Penegak Hukum", Jurnal Serviens in Lumine Veritatis, 2,

8 Johan Prinsloo and Brian Kingshott, "Ethic in Policing", Jurnal Phronimon, Volume 5, Number 1, Year 2004, H. 51,

${ }^{9}$ Sadjijono, Hukum Kepolisian Kemandirian, Profesionalisme dan Reformasi POLRI, Laksbang Grafika, Surabaya, 2014, 156

${ }^{10}$ Rohman, Marlina, Analisis Yuridis terhadap Polri dalam melakukan Pelanggaran Kode Etik (Studi di SPN Sampali Medan), Jurnal Mercantoria, Volume 11 Nomor 2, Desember 2018, 144.
} 
guidelines, functions and sanctions for violations committed in the corridor of their duties and corridor of criminal acts outside their authority. This Law was followed by a Decision of Kapolri No. Kep/32/VII/2003 concerning Ratification of the Formulation of the Profession Ethical Code of the State Police of the Republic of Indonesia and a Decision of Kapolri No. Pol.Kep/33/VII/2003 on July 1, 2003 concerning Operating Procedure of a Commission of Ethical Code of the State Police of the Republic Indonesia. The fulfillment of the Profession Ethical Code of the State Police of the Republic of Indonesia is not only done internally, but also must pay attention to the provisions of Article 7 paragraph (4) of Law No. 10 of 2004 concerning Formation of Legislation to prioritize regulations with a higher hierarchy to be implemented first. Law enforcement for police officers must be done professionally and transparently in order to maintain public trust ${ }^{11}$.

\section{a. The Implementation of the Profession Ethical Code of the State Police of the Republic of Indonesia}

The Profession Ethical Code of the State Police of the Republic of Indonesia is a code of conduct as well as a moral guideline for the State Police officers as an effort to glorify police profession. The Profession Ethical Code of the State Police of the Republic of Indonesia has sanctions consisting of stipulations of disgraceful actions, compulsion to make apologies, professional development and/or determination of professional infidelity. In the event that the violation is considered to be mild, the sanctions can be reprimand, professional education, salary postponement, transfer, and release from office. ${ }^{12}$

Any violation against the Profession Ethical Code is subject to moral sanctions conveyed in the form of a written decision of a Commission of Ethical Code. Article 12 Paragraph 4 of Regulation of Kapolri No. 14 of 2011 states administrative sanctions in the form of recommendations for transfer of duties or termination of duties must be known and/or approved by Ethical Code Commission. The Ethical Code Commission is a representation of Polri in an effort to glorify Police profession from bad deeds committed by Polri officers. The Commission's examination was an attempt to prove the alleged violation against the Profession Ethical Code of the State Police of the Republic of Indonesia.

Meanwhile, violations against disciplinary and profession ethical code will be examined and sentenced by Police officers if they are proven by permanent legal force. In imposing these sanctions, it does not eliminate the criminal acts committed by Police officers as referred to in Article 12 Paragraph (1) of Government Regulation No. 1 of 2003 juncto Article 28 paragraph (2) of Regulation of Kapolri No. 14 of 2011. Therefore, police officers who have committed a corruption will continue to be examined and legally processed by the authorized official, in this case the Corruption Eradication Commission (KPK), even though the police officers have been subjected to disciplinary sanctions and sanctions for violating Profession Ethical Code in Internal Police Department.

\section{b. The intersection of the Profession Ethical Code of the State Police of the Republic of Indonesia and the Corruption Law}

Regulations on the Code of Ethics and Discipline will continue to apply within the Internal Police Department. Meanwhile, if a police officer commits a criminal act of corruption, he will be treated as a civilian who will be processed in General Court, namely Corruption Criminal Court. Article 29 Paragraph 1 of Law on Police states that police officers committing a criminal act of

\footnotetext{
${ }^{11}$ Krisna Monita Sari. "Penegakan Hukum terhadap Anggota Polri yang Melakukan Tindak Pidana Narkoba". Logika : Journal of Multidisciplinary Studies, ISSN 2085-9970. Vol. 10 Nomor 01 Juni 2019. 51-59.

${ }^{12}$ Nestiti Aroma dan Untung Srim Amiek, "Pelaksanaan Tugas dan Wewenang Komisi Kode Etik Kepolisian Republik Indonesia (Studi Kasus pada Kepolisian Daerah Jawa Tengah)", Dipenogoro Law Journal, Volume 5, Nomor 3, Tahun 2016,3 .
} 
corruption will be treated as civilians as there has been an examination on the elements of corruption, including elements of office, facilities and abuse of authority arising from the profession ethical code and/or legislation. It shows that members of the state police of the Republic of Indonesia are civilians and are no longer subject to military law. Although the members of the state police of the Republic of Indonesia are civilians, they will also subject to the Disciplinary Rules and Profession Ethical Code when committing serious violations related to Corruption. The implementation of the Profession Ethical Code is carried out and extended to rules relating to legislation that are intended to members of the state police of the Republic of Indonesia. ${ }^{13}$ Under certain conditions, the implementation of the profession ethical code is also carried out discreetly by Kapolres in a coordinative manner in accordance with the principles of administrative law. ${ }^{14}$ However, it should also be noted that the implementation of legal norms of legislations and legal norms of profession ethical code shall prioritize the legal norms of legislations as a valid and objective legal subject. In this case, the profession ethical code as a part of rules can be ruled out, especially in the event that violations against the profession ethical code will disturb and/or affect the implementation of other legislations.

In addition, it also relates to which party who has the authority to deal with the violations against profession ethical code as well as applicable legislations. With the nature of criminal law which compels and provides sanctions, it must be viewed seriously by the police. The police cannot close the access or authority of other parties related to corruption as a special crime in the case that the institution directly takes over and requests a halt in processing the violations against the profession ethical code after an investigation. The police as the authority has limitations to carry out investigations and actions that result in legal violations having a broad impact. The Corruption Eradication Commission (KPK) as an institution that has the authority to process the abuse of authority and position carried out by members of the state police of the Republic of Indonesia which causes state financial losses based on Law on Corruption. KPK carries out the task of investigating and prosecuting against members of the state police of the Republic of Indonesia committing a corruption.

\section{Comparison of the Imposition of Legal Sanctions on Police Officers Proven to Commit Corruption in Singapore and Indonesia}

The existence of the legal status of Police as a part of the people of the Republic of Indonesia does not only make the Police to have a legal obligation to obey the applicable legislations. In a broader sense, police ethical code between one jurisdiction and another is also different due to the existence of society values. It is because the police do not only play a role in the field of profession, but also in implementing law in state administration as a state institution. This legal position is also stated in the Profession Ethical Code of the State Police of the Republic of Indonesia Article 13 paragraph 1 of Regulation of Kapolri No. 14 of 2011 concerning the Profession Ethical Code of the State Police of the Republic of Indonesia that there is a prohibition as a perpetrator, a party who orders or who participates in carrying out Corruption, Gratification and/or KKN (Collusion, Corruption and Nepotism). In addition, the simultaneous implementation of the code of ethics and legislation is an implementation of Democratic System, namely the enforcement of the Rule of Ethics and the Code of Ethic in an independent Court of Ethic. ${ }^{15}$ Indonesia shall implement law enforcement that is free from the principle of justifying any means which then has the potential to violate legal

\footnotetext{
${ }^{13}$ Nia Dian Widiyani, "Penanganan Terhadap Polisi yang melanggar Kode Etik Profesi Kepolisian (Studi di Polisi Resort Malang)", Jurnal Hukum Universitas Brawijaya, Mei 2014, 7.

${ }^{14}$ Son Haji, Gunarto dan Widayati, "Implementasi Kewenangan Direksi Kepolisian Dalam Penanganan Tindak Pidana di Polres Demak Jawa Tengah", Jurnal Hukum Khaira Ummah, Volume 13, Nomor 1, Maret 2018, 54.

${ }^{15}$ Jimly Asshiddiqie, "Peran Lembaga Etik Dalam Mengawasi dan Menjaga Kehormatan, Keluhuran Martabat dan Perilaku Pejabat Publik", H.2, <http://www.dpr.go.id/dokakd/dokumen/-53-eceb9a6ac608570bac5b53c2efbb95f5.pdf >
} 
provisions. ${ }^{16}$ In this regards, KPK in Indonesia has the authority to take over the authority of investigators and prosecution in accordance with the principle of trigger mechanism with the existence of the element of unwillingness in the institution. ${ }^{17}$

Corruption is not a crime that only threatens the Indonesian government. Governments in the world also face the same threat as corruption arises from social and economic motives. The abuse of authority or the opportunity owned by members of the police for their benefit or for the benefit of others is also a serious agenda for Singapore. Singapore does have a common law system that makes it implement the principle of stare decisis and judges' decisions which become landmark decisions. Yet, it cannot be denied that the implementation of judges' decisions cannot automatically be implemented in various ways and methods of corruption in Singapore. Similar to Indonesia, Singapore as a developed country in Southeast Asia also provides legal provisions relating to criminal acts of corruption. In Singapore, corruption is considered as an extraordinary crime along with bribery and money laundering. Singapore does not depend on customary law or jurisprudence. Singapore has formed special units in the police and formed an authorized agency to supervise and enforce criminal acts of corruption.

Although news about corruption in Singapore is not as much as Indonesia, Singapore is a country that has succeeded in eradicating corruption by uncovering and emphasizing corruptors, including in police institutions, through periodic supervision conducted by Ministry of Home Affairs and Corrupt Practices Investigation Bureau ${ }^{18}$. The coordination between the police and the government conducted by Singapore is the same as Indonesia, but the difference is that the code of ethics applied in the Singapore police can differ from Indonesia depending on the legal system and the tendency of violations in Singapore and in Indonesia, as well as an integrated supervision system between internal and external parties of the institutions.

Besides, there is also a difference on the implementation mechanism of the Prevention of Corruption Act which allows the Corrupt Practices Investigation Bureau (CPIB) to examine suspected corruption in all aspects of private and public legal relations, including police institutions, and to analyze the legal relationships and opportunities for corruptors to cooperate with other parties. ${ }^{19}$ Similar to Indonesia, CPIB given the authority to intervene and carry out actions on corruption criminal acts in private and public law is indirectly given the authority to supervise the implementation of a code of ethics in the police.

In detail, CPIB can also play a role as a supervisor as well as a supporter in the implementation of the code of ethics. The duties of CPIB include:

a. Following up on reports or allegations of corruption in all layers of institutions, legal entities and private legal relations

b. Conducting examination and inspection on allegations of malpractice by public officials

c. Providing criticism and advice on codes of ethics or practices that apply in an institution to prevent and minimize corruption.

The success of Singapore in implementing the massive prevention of corruption is also widely emulated by other ASEAN countries. The recommendations that can be replicated are $:^{20}$

\footnotetext{
${ }^{16}$ Azies Bauw, "Penegakan Kode Etik Kepolisian Terhadap Pelanggaran yang dilakukan anggota polisi (studi kasus di kepolisian daerah jayapura)", Jurnal Legal Pluralism, Volume 5, Nomor 1, Januari 2015, 2.

17 Yasmirah M.S, Teguh Prasetyo dan Jawade Hafidz, "Analisis Yuridis Kewenangan Komisi Pemberantasan Korupsi sebagai Penuntut Pelaku Tindak Pidana Korupsi”, Jurnal Unifikasi, Volume 5, Nomor 1, Januari 2018, 38.

18 GAN : Business Anti Corruption Portal, "Singapore Corruption Report", dapat diakses di $<$ https://www.ganintegrity.com/portal/country-profiles/singapore/ >, Accessed pada 14 Juli 2019.

${ }^{19}$ Koh Teck Hin, "Corruption Control in Singapore", The 13th International Training Course On The Criminal Justice Response To Corruption Visiting Experts' Papers , $\quad$ H. $\quad$ 124, <https://www.unafei.or.jp/publications/pdf/RS_No83/No83_17VE_Koh1.pdf >

20 Jon S.T Quah, "Combating Corruption Singapore Style : Lesson for Other Asian Countries", Maryland Series in Contemporary Asian Studies, $\quad$ Number 2, $\quad$ Year $\quad 2007, \quad$ H. $\quad 37-42$,
} 
a. The institutional system and the rule of law relating to ethics and the prevention of criminal acts of corruption shall use appropriate political power. As we know that resolving conflicts between ethics and practice can be done through active appeals and supervision from the state.

b. Specific institutions that conduct prevention and settlement of corruption cases must be independent. The institutions should not have a conflict of interest with the police or parties who have greater political power.

c. The anti-corruption institutions must be ensured to be free from the possibility or act of corruption, either directly or indirectly with other parties.

Yet, it does not mean that the police have never committed a criminal act of corruption. The case of Edwin Yeo as a staff of CPIB with a sentence of 10 years in prison is an example. ${ }^{21}$ Thus, in this case, the enforcement of the police code of ethics in Singapore must still be enforced.

Referring to Part II Section 4 Paragraph 1 of the Singapore Police Force Act, the Singapore Police also have a mandate that is almost the same as Indonesia, especially with regard to the implementation of law, public order, and prevention of criminal acts. The Police code of ethics in Singapore is also inseparable from the Singapore Inspectorate and Compliance Office Guidance which divides Internal Ethic Control into several sections, namely Corrective, Preventive, Detective and Directive. ${ }^{22}$ This type of division does not exist in Indonesia, but the supervision and control of the code of ethics has been given to the Ethical Code Commission in collaboration with Propam and other supervisors within the state police institution. The existence of an integrated and rigid Internal Control is due to the tendency that the Police can universally commit criminal acts, especially Extra Ordinary Crimes such as Corruption.

Singapore recognizes the tendency for criminal acts of corruption, namely by providing money or goods, granting privileges in administrative or business assistance, asking for money or goods in providing public services, and giving money to the police or criminal protection services carried out by the public. ${ }^{23}$ These actions are also based on the obligations of both Indonesia and Singapore as a member of the United Nations to implement Article 7 of United Nations Code of Conduct for Enforcement Officials by the United Nations Human Rights Office of the High Commissioner which clearly requires all law enforcers to commit corruption and to take actions to prevent corruption. Furthermore, referring to Article 8 of the Code, the United Nations also requires concrete rules governing the ethics of law enforcers with obligations of supervision and reporting as well as internal control by superiors on a regular basis.

In Indonesia, the corruption criminal act which is based on state interests rather than personal interests of the police has been implemented with the enforcement of the Code of Ethics through the Propam Polri, the Commission of Ethical Code and/or Appellate Commission. The existence of state interests above police interests is also implemented by the Singapore Police Force Act Part III Division 1 Section 24 which gives authority to the state to impose criminal sanctions against police officers who are proven to have committed criminal acts. Meanwhile, the disciplinary violations will then be reported to the Disciplinary Officer in which its mechanism is regulated in the Singapore Police Regulations. Actors proven to have committed criminal acts will be subject to disciplinary sanctions as regulated in Section 40, namely Reprimand, Warning, Termination, termination of salary for more than 2 years, reduction of Special Rights, granting certain workload, etc. Yet, this must be

https://digitalcommons.law.umaryland.edu/cgi/viewcontent.cgi?referer=https://www.google.com/\&httpsredir=1\&article=11 $\frac{88 \& \text { context }=\text { mscas }}{21 \text { J }}$

21 Jeff Cuellar, Money Smart, "Singapore Top 5 Corruption Cases (So Far)", https://blog.moneysmart.sg/opinion/singapores-top-5-corruption-cases-so-far/ >, Accessed pada 14 Juli 2019.

22 Singapore Police Force, "Annual 2013 A Force for the Nation", https://www.police.gov.sg/ /media/spf/files/publications/pdf/pla/pla\%202013.pdfH. 12, Accessed 14 Juli 2019.

23 Jon S T Quah, "Preventing Police Corruption in Singapore : The Role of Recruitment, Training and Socialisation", The Asia Pacific Journal of Public Administration, Volume 28, Number 1, June 2006, 61-62. 
proven by satisfied evidence based on Reasonable Evidence and Reasonable Opportunity for the Guilt.

In addition to the existence of state interests as outlined in the legislation, Indonesia has divided the state legal system and the judiciary authority into religious court, general court, military court and state administrative court. The division of the judiciary system automatically becomes a guideline for the State Police to determine the mechanism and authorized jurisdiction. Although the existence of the judiciary system has been clear, but it should be noted that in the event that the state financial losses occur when the police officer has performed a legal duty or position, the injured party can request compensation from the state through the Decision of State Administrative Court.

Then, what if the corruption is allegedly committed by members of the police while carrying out their duties? Hence, a coordination of the internal police is needed. Yet, this coordination should not interfere with investigations conducted by internal investigators or prosecutors investigators or Corruption Eradication Commission investigators. In this case, the violations committed by the police officers should be considered regardless of which court has the authority to examine them. Thus, what needs to be done by the Police Ethical Code Commission is to examine and determine what violations committed and what sanctions that will be imposed on the police officer. The more severe the violations committed by the police officers will also affect the recommendations that will be given as sanctions.

The implementation of criminal sanctions rather than ethical code is also regulated in Article 29 of Law No. 2 of 2002 and Law No. 46 of 2009 concerning Corruption Court stating that the Corruption Court has the authority to examine, try and decide criminal corruption cases regulated in other Laws as a criminal act of corruption. These two legislations do not describe explicitly or implicitly the opportunity for legal processing for officials and/or other parties having internal regulations. Thus, it can be concluded that the imposition of sanctions based on internal regulations is an autonomous act of each respective institution, but it should not interfere with the investigation process until the implementation of the Decision of Corruption Court.

The autonomous and separate granting of rights to process the code of ethics also relates to the principles of Institutionalized Organizations ${ }^{24}$ which include emphasizing the existence of Regulations and Harmonization of organizational structure and behavior of the police, the implementation of the complexity of internal regulations, and special monitoring and evaluation to deal with violations. In addition, the implementation of sanctions of ethical code after criminal sanctions also occur because the state has given functions to police to help resolve corruption cases with an Integrated Criminal Justice System among the Police, Public Prosecutors, Corruption Eradication Commission, and Judges. This case may also underlie the coordination that must be carried out simultaneously by the Singapore police to coordinate with CIPB Officers, Police and Public Prosecutors in carrying out acts of corruption.

The implementation of Court Ethical Code and the implementation of Sanctions are based on the Decision of Corruption Court to prevent the arbitrariness of police as stated in Article 12 paragraph 1 of Government Regulation of the Republic of Indonesia No. 1 of 2003 concerning Dismissal of Members of the State Police of the Republic of Indonesia. The dismissal is the substance of a violation of the code of ethics by considering a court decision and authorized officials. The dismissal which is based on the Police Ethical Code is conducted at the Court of Commission of Ethical Code of the State Police of the Republic of Indonesia. As regulated in Government Regulation No. 3 of 2003 concerning Technical Implementation of General Court for Members of the State Police of the Republic of Indonesia, the processing stages of violations are:

\footnotetext{
${ }^{24}$ John P. Crank, "Institutional Theory of Police : a review of the state of the art", PIJPSM Volume 2, Nomor 2, Tahun 2003, 187-188,
} 
a. The violation will be examined by the Criminal Investigation Unit that has the function to examine every alleged crime committed by both the public and the police officers as stipulated in Regulation of Kapolri No. 19 of 2012 concerning Organizational Structure and Work Procedure of the Commission of Ethical Code of the State Police of the Republic of Indonesia. The examination stage is divided into several stages, namely receiving reports, examining witnesses and conducting introduction examinations, forming commission, appointing prosecutors, forming KKEP secretaries, conducting trial, and issuing decision of KKEP.

b. The inspections until the investigation process will be monitored and coordinated with Propram. This inspection can be carried out even though the police officer suspected of committing a corruption has submitted his case to a district court. Thus, in this case, the collection of evidence will also be carried out with the assistance of Public Prosecutor's Office.

c. Propam reports the investigation progress to the Commission of Ethical Code. In the event that Propam can prove the existence of a criminal act, Propam requests the the Commission of Ethical Code to process it with an ethics trial. Yet, in this case, there is an obligation to wait for the trial results from the district court.

d. If the criminal act of corruption is proven and the decision provides criminal sanctions to members of the State Police of the Republic of Indonesia, then the sanction will be a dishonorably dismissal.

The imposition of ethical code sanctions on violation cases by members of the Singapore police through the Singapore Police Force Act is also applied in a similar method to Indonesia which is through Disciplinary Proceeding. Referring to Police Regulations Section 5, disciplinary proceeding will use the method of presenting and examining witness statements using cross examination method. Before examining witnesses through Disciplinary Proceeding, the Disciplinary Committee must also ensure that there are reports of suspected police offenders, as stipulated in Section 10, to further allow the legal process for criminal prosecution or civil action to be settled in accordance with applicable Singapore law.

The processing of corruption criminal act by suspected police offenders is regulated in the Singapore Prevention of Corruption Act as a special regulation alongside the Singapore Penal Code. It is similar to Indonesia which regulates the specificity of regulations related to Corruption in the Prevention of Corrupt Act. Corrupt Practices Investigation Services (CPIB) Officers who are authorized to coordinate with the Singapore police and the Public Prosecutor will hand over cases of alleged criminal acts of corruption to the Civil Court with the Proceeding mechanism as regulated in the Rules of Court consisting of reading demands, answering questions, proving, and issuing decision by the Panel of Judges. The disciplinary proceeding will also present recommendations provided by Disciplinary Officers and a report to the Commanding Officer who will decide whether the violation committed by the police officer will have an impact on the dismissal of the police or there are other considerations that are sufficient to maintain the position of the police officer. The sanctions that can also be given, as regulated in Section 40 Paragraph 4, are in the form of imposition of fines and deductions of salary for a certain amount for a month.

\section{CONCLUSION}

The conclusion of this legal research is that the Police Code of Ethics is administrative in nature and applies to the internal police department. Thus, if there is a legal violation committed by a police officer, he shall wait for the decision whether the case is settled in court or not. In the event that a police officer is proven to have committed a criminal act of corruption, the ethical punishment given is a recommendation to be dishonorably dismissed. This decision cannot be contested. The mechanism for implementing the code of ethics in Singapore is not much different from Indonesia, 
namely by first waiting for the inkracht decision. The difference is that the implementation and supervision of the police code of ethics in Singapore is also a CPIB jurisdiction alongside the internal police itself.

\section{SUGGESTION}

Based on the description, the authors suggest that there is a need for socialization and legal action both internally and externally to implement a code of ethics and corruption law to foster respect and obedience to the Code of Ethics and regulations in order to prevent corruption.

\section{BOOKS}

\section{REFERENCES}

Sadjijono, 2009, Etika Profesi Hukum Suatu Telaah Filosofis terhadap Konsep dan Implementasi Kode Etik Profesi POLRI, Laksbang Mediatama, Yogyakarta.

Sadjijono, 2014, Hukum Kepolisian Kemandirian, Profesionalisme dan Reformasi POLRI, Laksbang Grafika, Surabaya.

Frans Magnis Suseno, Etika Abad ke-20, Kanisius, Yogyakarta, 2006

\section{JOURNALS}

Ahmad Yani. Sistem Pemerintahan Indonesia : Pendekatan Teori dan Praktik Konstitusi Undang Undang Dasar 1945. Jurnal Legislasi Indonesia, Volume 15, Nomor 2, Juli 2018.

Azies Bauw. Penegakan Kode Etik Kepolisian Terhadap Pelanggaran yang dilakukan Anggota Polisi (Studi kasus di Kepolisian Daerah Jayapura). Jurnal Legal Pluralism, Volume 5, Nomor 1, Januari 2015.

Johan Prinsloo and Brian Kingshott. Ethic in Policing, Jurnal Phronimon, Volume 5, Number 1, Year 2004.

John P. Crank. Institutional Theory of Police : A Review of the State of the Art", PIJPSM Volume 2, Nomor 2, Tahun 2003.

Jon S T Quah. Preventing Police Corruption in Singapore : The Role of Recruitment, Training and Socialisation. The Asia Pacific Journal of Public Administration, Volume 28, Number 1, June 2006.

Krisna Monita Sari. Penegakan Hukum terhadap Anggota Polri yang Melakukan Tindak Pidana Narkoba". Logika : Journal of Multidisciplinary Studies, ISSN 2085-9970. Vol. 10 Nomor 01 Juni 2019. 51-59.

Lundu Harapan Situmorang. Fungsi Kode Etik Kepolisian dalam Mencegah Penyalahgunaan Wewenang sebagai Aparat Penegak Hukum", Jurnal Serviens in Lumine Veritatis. Tahun 2016. https://core.ac.uk/download/pdf/84788913.pdf

Nestiti Aroma, Untung Srim dan Amiek, "Pelaksanaan Tugas dan Wewenang Komisi Kode Etik Kepolisian Republik Indonesia (Studi Kasus pada Kepolisian Daerah Jawa Tengah)", Dipenogoro Law Journal, Volume 5, Nomor 3, Tahun 2016.

Nia Dian Widiyani, "Penanganan Terhadap Polisi yang melanggar Kode Etik Profesi Kepolisian (Studi di Polisi Resort Malang)", Jurnal Hukum Universitas Brawijaya, Mei 2014.

Rohman dan Marlina, "Analisis Yuridis terhadap Polri dalam melakukan Pelanggaran Kode Etik (Studi di SPN Sampali Medan)”, Jurnal Mercantoria, Volume 11 Nomor 2, Desember 2018.

Son Haji, Gunarto dan Widayati, "Implementasi Kewenangan Direksi Kepolisian Dalam Penanganan Tindak Pidana di Polres Demak Jawa Tengah", Jurnal Hukum Khaira Ummah, Volume 13, Nomor 1, Maret 2018. 
Yasmirah M.S, Teguh Prasetyo dan Jawade Hafidz, "Analisis Yuridis Kewenangan Komisi Pemberantasan Korupsi sebagai Penuntut Pelaku Tindak Pidana Korupsi”, Jurnal Unifikasi, Volume 5, Nomor 1, Januari 2018, H. 38.

Krisna Monita Sari. "Penegakan Hukum terhadap Anggota Polri yang Melakukan Tindak Pidana Narkoba". Logika : Journal of Multidisciplinary Studies, ISSN 2085-9970. Vol. 10 Nomor 01 Juni 2019. 51-59.

\section{INTERNET}

$\mathrm{ACCH}$ atau Anti Corruption Clearing House, "Penindakan" 31 Desember 2018, https://acch.kpk.go.id/id/statistik/tindak-pidana-korupsi

Andylala Waluyo , VOA Indonesia, "KPK Jerat 2 Jenderal Polisi dalam Kasus Korupsi 198 M", 3 Agustus 2012, https://www.voaindonesia.com/a/kpk-jerat-2-jenderal-polisi-dalam-kasuskorupsi-rp-198m/1454257.html

GAN : Business Anti Corruption Portal, "Singapore Corruption Report", <https://www.ganintegrity.com/portal/country-profiles/singapore/>

Jeff Cuellar, Money Smart, "Singapore Top 5 Corruption Cases (So Far)", https://blog.moneysmart.sg/opinion/singapores-top-5-corruption-cases-so-far/ >

Jimly Asshiddiqie, "Peran Lembaga Etik Dalam Mengawasi dan Menjaga Kehormatan, Keluhuran Martabat dan Perilaku Pejabat Publik", <http://www.dpr.go.id/dokakd/dokumen/-53eceb9a6ac608570bac5b53c2efbb95f5.pdf >

M Azhar dan PDAT, Tempo, "Jenderal Polisi di Pusaran Korupsi", 7 Agustus 2012, https://nasional.tempo.co/read/421944/jenderal-polisi-di-pusaran-korupsi/full\&view=ok

Singapore Police Force, "Annual 2013 A Force for the Nation", https://www.police.gov.sg/ /media/spf/files/publications/pdf/pla/pla\%202013.

\section{PAPER}

Jon S.T Quah, "Combating Corruption Singapore Style : Lesson for Other Asian Countries", Maryland Series in Contemporary Asian Studies, Number 2, Year 2007, https://digitalcommons.law.umaryland.edu/cgi/viewcontent.cgi?referer=https://www.google.co $\underline{\mathrm{m} / \text { \&httpsredir }=1 \& \text { article }=1188 \& \text { context }=\text { mscas }}$

Koh Teck Hin, "Corruption Control in Singapore", The 13th International Training Course On The Criminal Justice Response To Corruption Visiting Experts' Papers $\langle$ https://www.unafei.or.jp/publications/pdf/RS_No83/No83_17VE_Koh1.pdf $>$ 